\title{
Oat (Avena sativa L.): Oil and Nutriment Compounds Valorization for Potential Use in Industrial Applications
}

\author{
Nihed Ben Halima ${ }^{1, *}$, Rania Ben Saad ${ }^{2}$, Bassem Khemakhem ${ }^{3}$, Imen Fendri ${ }^{4}$ and \\ Slim Abdelkafi ${ }^{1}$ \\ ${ }^{1}$ Biological Engineering Department, National School of Engineers of Sfax, University of Sfax, Sfax, Tunisia. \\ ${ }^{2}$ University of Sfax, LPAP, Centre of Biotechnology, Sfax, Tunisia. \\ ${ }^{3}$ Laboratoire d'amélioration des plantes, Facultés des Sciences de Sfax, University of Sfax, Tunisia \\ ${ }^{4}$ Unité de Recherche Toxicologie - Microbiologie Environnementale et Santé, Faculté des Sciences de Sfax, Université de Sfax, Sfax, Tunisia.
}

\begin{abstract}
Oat is a promising plant for the future. It is edible and beneficial thanks to its nutritional, medicinal and pharmaceutical uses and, hence, recognized to be useful for a healthier world. The assessment of the vital functions of oat components is important for industries requiring correct health labelling, valid during the shelf life of any product. Oil, enzymes and other biomolecules of nutraceutic or dietary usage from oats would be valorized for this purpose. Although oats have a unique and versatile composition including antioxidants and biomolecules indispensable for health, they are undervalued in comparison with other staple cereals such as wheat, barley and rice. Furthermore, oats, apart from maize, comprise a high oil content used for a wide range of beneficial purposes. In addition, they contain beta glucan that has proven to be very helpful in reducing blood cholesterol levels and other cardiovascular diseases risks. In fact, there is diversity in the composition and content of the beneficial oat components within their genotypes and the different environmental conditions and, thus, oats are amenable to be enhanced by agronomic practices and genetic approaches.
\end{abstract}

Key words: oat, lipids, antioxidant constitutes, biomolecules, industrial applications

\section{INTRODUCTION}

Cereals constitute the main source of food; they are also nutraceutical and therapeutical agents as they contain various types of beneficial elements such as starch, proteins, fiber, lipids and other medicinal compounds. Besides, they have also been found to contain a wide range of chemical substances with a high antioxidant activity ${ }^{1)}$. Among such cereals we can cite oats which belong to the Poaceae family (Gramineae) (Table 1). Wild oats are diploid, but those cultivated are hexaploid with an estimated $1 \mathrm{C}$ genome size of $13.23 \mathrm{pg}$, corresponding to about $13000 \mathrm{Mbp}^{2)}$. The common oat (Avena sativa L.) is an allohexaploid $(2 \mathrm{n}=6 \mathrm{x}=42)$ crop species. Furthermore, Flander et $a l .{ }^{3)}$ showed that the whole oat grain contains many of these nutritional compounds, including minerals, proteins, fiber, lipids, unsaturated fatty acids, vitamins and phytochemicals. The common Avena sativa L. is the most important cultivated oat and it is also the most unusual compared with other cereal grains due to the storage of high amounts of oil in the endosperm which can be up to $90 \%$ of the total grain oil ${ }^{4)}$. Plants with oilseed represent many versatile commodities due to their use essentially in food, feed and medicine. The demand for these important agriculture crops is increasing since they constitute a renewable alternative to fossil oil. Unlike other cereals which accumulate oil in the embryo, scutellum, and aleurone layer, oat oil (Avena sativa L.) in kernels is deposited mostly in the same starch-accumulating endosperm cells. Therefore, several reports ${ }^{5-7)}$ focused on oat endosperm as a desirable model tissue to study carbon allocation into oil, such as carbon partitioning between oil and carbohydrates $^{8)}$ or preferred carbon precursors for lipid labelling in the heterotrophic endosperm ${ }^{4)}$.

Oats (Avena sativa L.) are cultivated for grain, fodder, straw, and feed ${ }^{9)}$ over more than 9 million hectares global$\mathrm{ly}^{10)}$. This important multi-purpose cereal is widely grown

*Correspondence to: Nihed Ben Halima, Biological Engineering Department, National School of Engineers of Sfax, University of Sfax, Sfax, Tunisia.

E-mail: nihedbenhalima@gmail.com

Accepted June 2, 2015 (received for review March 30, 2015)

Journal of Oleo Science ISSN 1345-8957 print / ISSN 1347-3352 online

http://www.jstage.jst.go.jp/browse/jos/ http://mc.manusriptcentral.com/jjocs 
N. Ben Halima, R. Ben Saad and B. Khemakhem et al.

Table 1 Taxonomic information ${ }^{12)}$.

\begin{tabular}{ll}
\hline Kingdom & Plantae: plants \\
Superdivision & Spermatophyta: seed plants \\
Division & Magnoliophyta: flowering plants \\
Class & Liliopsida: monocotyledons \\
Order & Cyperales \\
Family & Poaceae: grass family \\
Genus & Avena: oat \\
Species & A. sativa: common oat, A. byzantina, A. fatua, A. diffusa, A. orientalis \\
\hline
\end{tabular}

as a spring crop mostly in cool moist climates. It can also be adapted to autumn sowings as mentioned by SánchezMartín et al. ${ }^{11)}$ who assessed the adaptation of 32 modern oat cultivars from different origin and usage to the autumn sowings under Mediterranean agroecological conditions, including Tunisia, Spain, Egypt and Palestinian Territories characterized by hot and dry weather. Their study helped in the easy breeding of adaptive oat within the Mediterranean area.

Oats are nutritious palatable foodstuffs responsible for the supply of carbohydrates, mainly in the form of starch with a considerable amount of lipids as well as a reasonable level of much of our micronutrients intake (Table 2).

Oats are produced on a global scale. The Food and Agriculture Organization $(\mathrm{FAO})^{10)}$ indicated that the global oat production in 2012 was 19.6 megatons, while The US Department of Agriculture ${ }^{15)}$ announced a preliminary figure of a global oat production in 2013/2014 of about 23.6 megatons, which means a $10.6 \%$ increase compared with the 2012/2013 harvest. In Tunisia, oats are the most important livestock feed ${ }^{16)}$, and the indication of the $\mathrm{FAO}^{10)}$ estimated an oat production of 1700 tons in Tunisia with more than 4000 hectares harvest area in 2013.

Oats have preferred regions for growth. They favour temperate regions, especially Russia, North America and Mid to North of Europe that comprise the major oat production regions (Fig. 1). Hence, moderate temperature and day length are the optimum growth conditions. Among cereals, oats have the advantage of tolerating acidic soils and wet weather more effectively; they are also relatively resistant to foliar diseases and require comparatively fewer fertilizer and pesticide inputs ${ }^{17)}$.

The impact of agronomic systems and environmental factors, including abiotic stressors such as temperature, fertilization and drought/flooding has been assessed on the health-beneficial and nutritive values of oat components ${ }^{18)}$.

Plant pathogens (viruses, fungal infections, etc.) constitute the major threat for oats. They affect negatively both the crop yield and the quality of oat. For example, the barley yellow dwarf virus can significantly reduce crop yield ${ }^{19)}$. Also, the powdery mildew (Blumeria graminis ${ }^{20,21)}$ and the crown rust (Puccinia coronata ${ }^{22)}$ are the most
Table 2 Oatmeal nutritional composition*.

\begin{tabular}{|c|c|}
\hline Component & Oatmeal (100 g) \\
\hline \multicolumn{2}{|l|}{ Energy } \\
\hline Kcal & 401 \\
\hline $\mathrm{KJ}$ & 1678 \\
\hline Carbohydrate (g) & 72.8 \\
\hline Protein $(\mathrm{g})$ & 12.4 \\
\hline Oil (g) & 8.7 \\
\hline Dietary fiber $(\mathrm{g})$ & 6.8 \\
\hline $\mathrm{P}(\mathrm{mg})$ & 380 \\
\hline $\mathrm{K}(\mathrm{mg})$ & 370 \\
\hline $\mathrm{Mg}(\mathrm{mg})$ & 110 \\
\hline $\mathrm{Ca}(\mathrm{mg})$ & 55 \\
\hline $\operatorname{Se}(\mu \mathrm{g})^{* *}$ & 8.6 \\
\hline $\mathrm{Fe}(\mathrm{mg})$ & 4.1 \\
\hline $\mathrm{Zn}(\mathrm{mg})$ & 3.3 \\
\hline Niacin (mg) & 3.8 \\
\hline Vitamin E (mg) & 1.7 \\
\hline Thiamin (mg) & 0.50 \\
\hline $\mathrm{Cu}(\mathrm{mg})$ & 0.23 \\
\hline Vitamin $B_{6}(\mathrm{mg})$ & 0.12 \\
\hline Riboflavin (mg) & 0.10 \\
\hline Folic acid $(\mu \mathrm{g})$ & 60 \\
\hline $\begin{array}{l}\text { * The data are taken } \\
\text { Database }^{14)} \text {. }\end{array}$ & ${ }^{13)}$ and USDA Nu \\
\hline
\end{tabular}

widespread fungal diseases in the cool, humid regions of Europe and North America, respectively. But, the most fungal infections affecting cereals, in particular oats, are those caused by the Fusarium genus species which are known to produce hazardous mycotoxins such as nivalenol, deoxynivalenol, zearalenone and trichothecenes T-2 and HT-2. These toxins can be responsible for chronic toxicity which can induce apoptosis in the immune system and 


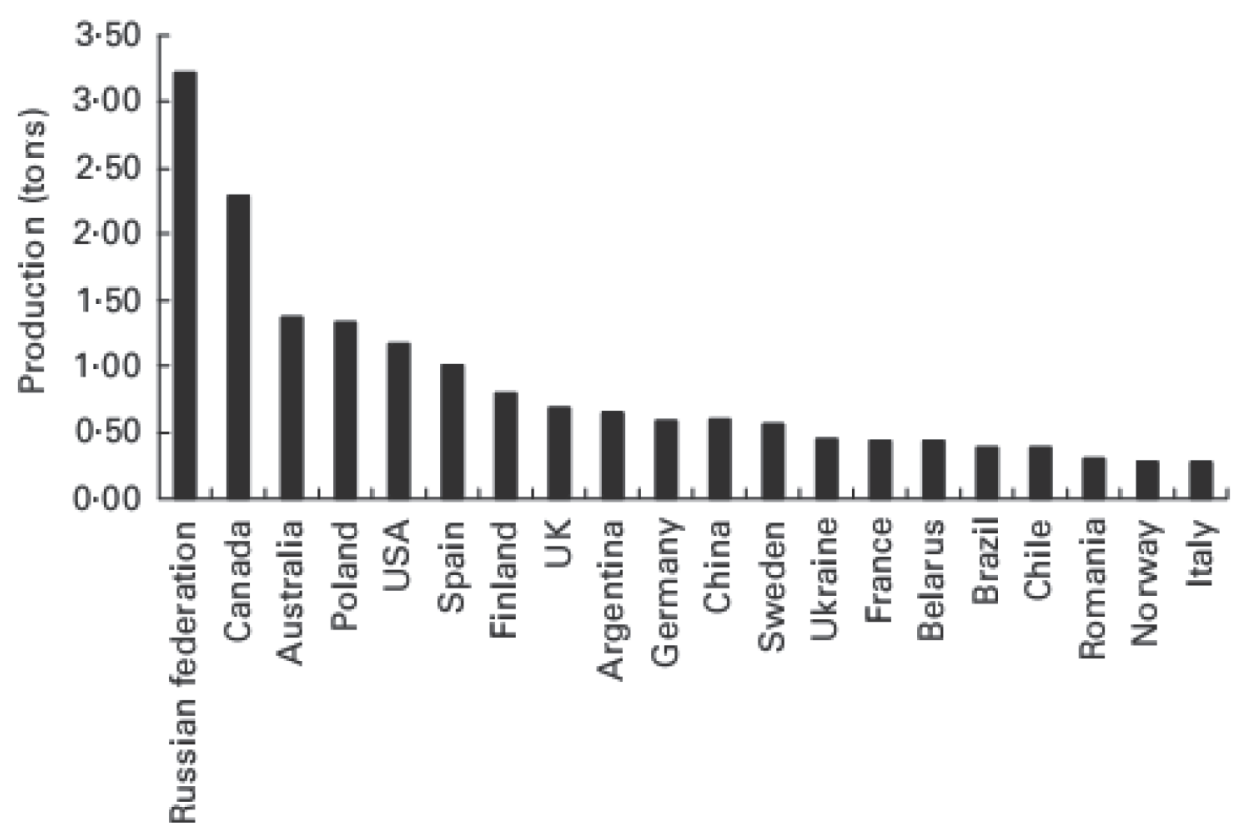

Fig. 1 Top twenty oat-producing countries in $2010^{10,18)}$.

fetal tissues ${ }^{23)}$. In fact, the specific production of such toxins depends on oat growth localization ${ }^{24,25)}$. Therefore, implementing modern agricultural practices and/or developing new varieties of pathogen-resistant oats would be necessary to prevent pathogens attacks.

We can also note that different processing techniques on oats such as malting and roasting can help in keeping their high nutritive value and their resulting weaning mixes; it is also found that both oat roasted and malted weaning gruels are accepted by the panel members of sensory quality evaluation $^{26)}$. Thus, child malnutrition, caused by the introduction of traditional weaning foods, would be improved by simple processing techniques on cereals such as oats whose formulated weaning mix is being increased in nutritional value ${ }^{26,27)}$.

Besides, oats have long been considered as a source of various characteristic constituents such as saponins, among which triterpenoid saponins are used as monocots biomolecules exerting dietary and nutraceutic potential ${ }^{28)}$. Thus, the common oat (Avena sativa L.) is subject to many industrial applications.

\section{DESCRIPTION OF OAT CONSTITUENTS}

\subsection{Proteins}

Oat protein content varies between 15 and $20 \%{ }^{29)}$. Globulins which comprise $50-80 \%$ and avenins $10-20 \%$ of the seed proteins are therefore the two dominant classes $^{30,31)}$. Globulins (salt-soluble proteins) are abundant in oats compared with other cereals, thus conferring a higher nutritional value because of this class favorable composition in essential amino acids ${ }^{32)}$. Yet, it is worth noting that when oat globulins are present in aqueous salt solutions between pH 4-5, they are insoluble ${ }^{33)}$, thus limiting the use of oat in some products ${ }^{34}$. Avenins or prolamins (alcohol soluble proteins) are rich in proline and glutamine amino acids and are associated with celiac disease ${ }^{31}$. Oat lipids are present in aqueous extracts and their proteins are poorly soluble, so emulsion, foam formation and stabilization are relatively not important. Konak et $a l .{ }^{34)}$ reported that $\mathrm{CO}_{2}$-defatted oat flour improves foaming and emulsifying properties at basic $\mathrm{pH}$ values. In addition, the works of Sibakov et al. ${ }^{35)}$ are in agreement with the fact that the removal of oat lipids by supercritical carbon dioxide $\left(\mathrm{SC}-\mathrm{CO}_{2}\right)$ enhances the separation of grain cell wall material from starch and protein. Consequently, $\mathrm{CO}_{2}$-extracted oats can be useful raw materials in beverages and other aqueous applications, where protein functionality plays an important role $^{34)}$ in gelling, solubility and surface stabilization properties such as foaming and emulsifying ${ }^{36)}$. It is also important to focus on the better solubility of such proteins which play an evident role in the products texture, color, sensory and organoleptic characteristics ${ }^{37)}$.

\subsection{Lipids}

\subsubsection{Oat lipids: generalities}

Oats contain a wide range of active compounds, including avenanthramides, starches, hydrocolloid $\beta$-D-glucan, vitamins, saponins and other antioxidants (mostly phenolic esters) and a relatively high content of total lipids with a high unsaturated fatty acids percentage ${ }^{38,39}$. Total lipids can reach $18 \%{ }^{40,41)}$, and about $41 \%$ of the groat lipids are triacylglycerols, while $5 \%$ are free fatty acids ${ }^{42}$. Thus, oats 


\section{N. Ben Halima, R. Ben Saad and B. Khemakhem et al.}

grain has the highest capacity to accumulate an important amount of oil in the endosperm compared with other cereals; it is also important to note that maize is the only cereal having similar high grain oil content to that of oats, but it accumulates oil mostly in the embryo ${ }^{43)}$. In view of this fact, among all cereals, oat oil in the endosperm remains the only particular lipid to be studied.

Peterson and Wood ${ }^{41)}$ described the composition and structure of oat (Avena sativa L.) selections with elevated oil concentrations ranging from 6.9 to $18.1 \%$. These highoil oats were obtained from recurrent selections breeding regime at Iowa State University. It was shown that, in these selections, tocotrienols concentration located predominantly in the endosperm was correlated with oil concentration unlike that of tocopherols which are concentrated in the germ. On the other hand, $\beta$-glucan and protein concentrations increased, whereas those of starch decreased with increasing oil concentrations ${ }^{41)}$.

White et $a l^{44)}$ suggested an intrinsic association between oat oil bodies and the E-vitamers. The latter, which are compounds metabolically and chemically related to vitamin $\mathrm{E}$ and with the same biological activity, are present in oats with significant levels. Therefore, these E-vitamers would be responsible for the oxidative stability of the membrane and/or oat oil bodies ${ }^{44)}$.

Martinez et $a l{ }^{45)}$ evaluated different oat cultivars for grain yield, lipid profile and nutrient content during two years (2004 and 2005) in different climatic conditions. All variables tested seemed to be more influenced by environment than by genotype ${ }^{45)}$ and, thus, Zhou et $a l{ }^{46)}$ noted that it is possible to improve oat fatty acids composition through breeding procedures.

Banas et al. ${ }^{5)}$ provided for the first time a characterization of lipid deposition and fatty acid composition in different parts of the oat grain tissues during grain development using two kinds of oat cultivars, one with medium oil (6\%) (Cultivar Freja) and another with high oil (10\%) (Matilda cultivar). Hence, the major part of the grain lipids (86-90\%) was found and stored in the endosperm as shown by chemical and microscopical analyses ${ }^{5,47)}$. Up to $84 \%$ of the oat lipids were deposited in the endosperm during the first half of grain development when seeds were still green with a milky endosperm ${ }^{5)}$.

Microscopy studies revealed that oil bodies fused in the starchy endosperm with less associated proteins (oleosins) upon maturation and, thus, formed smears of oil, while they were intact in the embryo, scutellum and aleurone layer ${ }^{5,47)}$.

Therefore, Heneen et al. ${ }^{47)}$ showed that most stored oil areas were close to the enzymes production sites related to mobilization and germination. Yet, Leonova et al. ${ }^{48)}$ who studied lipid reserves mobilization in different tissues during oat germination (Avena sativa L.) proved by transmission electron microscopy that the oil droplets which ap- peared in areas close to the scutellar epithelium and the aleurone of oat grain were oil bodies surrounded by oleosins. Oleosins stabilize and prevent oil bodies fusion and contribute to facilitate lipase activity to rapidly mobilize fatty acids during oil seeds germination ${ }^{49,50)}$. Oil seeds storage constitutes a form of energy (triacylglycerol(TAG)) which can be mobilized by the action of lipases which release free fatty acids (FFAs) from this oil and can be degraded under $\beta$-oxidation and glyoxylate cycles and which are subsequently converted into sugars ${ }^{48,51,52)}$. But the cereal endosperm is known to be a dead tissue in the mature grain, so this $\beta$-oxidation does not occur there. Leonova et $a l .^{48)}$ tried to determine the fate of these endosperm lipids during germination in cereal grains with the use of oat as a model. Their results suggest that the TAG of oat endosperm oil is not a dead-end product because, microscopically, it was absorbed by the scutellum, either as a form of FFA released from TAG or as an intact TAG form immediately degraded to FFAs; these lipids may be transported from the scutellum into the embryo ${ }^{48)}$.

In fact, the large amount of lipids in many seed dicotyledonous plants accumulates in their endosperm, where they are broken down through $\beta$-oxidation for energy production during germination. When the endosperm reserves are exhausted, a programmed cell death takes place in this endosperm ${ }^{53)}$. However, this death is undergone in the endosperm of monocotyledons mature grains ${ }^{54)}$, thereby $\beta$-oxidation is not involved during germination ${ }^{5)}$. Banas et $a l .{ }^{5)}$ demonstrated that amylases and proteases, which are mainly secreted from the aleurone layer of monocotyledons grains, were involved in the mobilization of their endosperm reserves and that the produced sugars and amino acids were taken up by the growing embryo. Indeed, during germination, nutrients stored in the cereals endosperm are degraded by the corresponding enzymes which are synthesized and secreted from the scutellum and the aleurone tissues which transport the enzymatic products (nutrient molecules) from the absorptive scutellum to nourish the growing embryo ${ }^{55)}$. Moreover, reports have markedly studied starch and proteins degradation in the cereals endosperm during germination as it is implicated in malting and food industries ${ }^{55-57)}$. However, there have been few reports on cereal lipid degradation during germination, and some studies have been concerned with only how oat oil processing can interfere in food industry ${ }^{58)}$. Lehtinen $e t$ $a l{ }^{59)}$ demonstrated that some oat lipid fractions were susceptible to be normally used at high temperature. Also, Kaukovirta-Norja et $a l{ }^{58)}$ noted that oat lipids stability and their prevention of off-flavour formation are effective in oat processing industry due to the fact that oat has a high lipid content and a high native lipolytic activity. Therefore, the oil mobilization in the cereals endosperm has not been well investigated. Fortunately, Leonova et $a l^{48)}$ focused on this issue and described lipid mobilization during oat germina- 
tion (Avena sativa L.). Hence, due to the negative correlation between starch and increased oil content in the oat grains ${ }^{40)}$, the concept of lipid mobilization during oat germination requires further research and interest for breeding high-oil cereal cultivars ${ }^{48)}$.

2.2.2 Oat lipids: dermatological effects

Compared with other cereals, the specific feature of Avena sativa L. grains is the high oil content which can range from $3 \%$ to $18 \%$ of the grain weight in different cultivars $^{5,40,41)}$, and deposited mainly in the grain endosperm tissues $^{60,61)}$. But in general, most oat cultivars comprise about $5-6 \%$ of oil and 55-60\% of starch in the grain ${ }^{5,62,63)}$, and high-lipid oat remains a potential oil crop ${ }^{47)}$. The main fatty acids in oat oil are palmitic acid (C 16:0), oleic acid (C18:1) and linoleic acid (C18:2) which account in total for about $90-95 \%{ }^{62,64)}$ regardless of the extraction method, variety or location ${ }^{45,46)}$. In addition, Leonova et al. ${ }^{65)}$ analyzed the quality and content of oat oil(Avena sp.) in 33 accessions from 13 wild species and 10 accessions of cultivated oat. They found that C18:1 FA content was higher in wild oat species. The cultivated oats and, interestingly, found unusual FAs. The latter consisted of minor amounts of several hydroxy and epoxy FAs trapped mainly in specific classes of lipids such as 15-hydroxy 18:2 $\Delta^{9,12}$ (avenoleic acid) which are mostly found among polar lipids, and a novel 7-hydroxyhexadecanoic acid found in 1,2-diacylglycerol.

Oats are particularly rich in monounsaturated oleic acid (18:1) and polyunsaturated linoleic acid (LA) (18:2) accounting for approximately 40 and/or $36 \%$ of the total oat oil, respectively ${ }^{46,64)}$. It is worth noting that the percentage of oil oat reported in the literature varies according to the extraction method, cultivar and storage ${ }^{42)}$. Recently, oat and oat oil have been investigated for their beneficial dermatological effects ${ }^{66,67)}$ and it is likely that the oat LA fraction plays a major role in the maintenance of the epidermal water barrier $^{68)}$.

Patients with an atopic skin have a compromised skin barrier which allows entry of many pathogenic agents causing the water loss rate to increase, which makes daily skin care, moisturization and cleaning mandatory for these patients. In order to limit further exacerbate the atopic dermatitis, protect the barrier and ensure a healthy skin, a daily oat-based skin care regimen for an atopic skin is very effective $^{66)}$. In fact, after two weeks treatment with a gentle oat-based daily skin care regimen, significant improvements were observed by an independent dermatologist. Thus, patients perceived skin benefits such as a better skin texture and an overall improved look and feeling ${ }^{66)}$. In addition, Southall et al. ${ }^{67)}$ demonstrated that oat oil improves the skin barrier as it is rich in LA which is an essential polyunsaturated fatty acid critical for the maintenance of the skin permeability barrier ${ }^{69)}$. Therefore, oat lotion proved to be highly useful in alleviating itch, ameliorating the skin barrier and effectively improving dryness and roughness associated with moderate to severe dry skin ${ }^{67)}$.

Finally, it can be noted that recently Feng et $a .^{70)}$ demonstrated for the first time the protective effect of oat at the cellular level due to the antioxidant properties of oat bran extract by enzymatic hydrolysates which prevents human dermal fibroblast injury induced by hydrogen peroxide $\left(\mathrm{H}_{2} \mathrm{O}_{2}\right)$. Yet, precautions should be taken as regards for long time cream based Avena sativa application or intolerance of this plant ${ }^{71}$.

In conclusion, oat can be a promising agent in preventing and improving dermal injuries; hence, further research is required to probe into the benefits and efficiency of oats as a protective and preventive factor.

\subsubsection{Oat lipids: protective effect on reprotoxicity}

Ben Halima et $a l .{ }^{64)}$ showed the positive effect of oat oil as a preventive agent on reprotoxicity in male mice induced by deltamethrin which is a pyrethroid pesticide exerting a wide range of effects on non-targeted organisms. Other reports demonstrated that pesticides could induce damage to reprotoxicity in vivo such as testicular injury or decrease testicular steroidogenesis in rats/mice ${ }^{72-74)}$.

Moreover, it is recognized that tocopherols (vitamin E) deficiency impairs mammalian fertility ${ }^{75,76)}$.

It was proven that reprotoxicity caused to mice by orally administered deltamethrin (DEL) can be effectively antagonized by the beneficial effects of oats oil as a potential antioxidant including a considerable amount of tocopherols to alleviate testis oxidative damage induced by this pesticide. In fact, what Ben Halima et al. ${ }^{64)}$ reported consisted in an in vivo study in which thirty-two male albino mice were divided into four equal groups: group 1 served as a control group; group 2 received deltamethrin (5 mg per kg b.w.); group 3 was administered deltamethrin after receiving oats oil (6 g per kg b.w.) and group 4 received only oats oil. Results showed that exposure to deltamethrin at a dose of $5 \mathrm{mg}$ per kg b.w. per day caused oxidative stress in testis, evidenced by a decrease in the epididymal sperm count and motility, an increase in the number of abnormal morphologies in spermatozoa and a significant increase in lipid peroxidation compared with control animals. Co-administration of oats oil to the DEL-treated mice, however, ameliorated the testicular biochemical parameters as well as the histological impairments in testis. Thus, oats oil can be an efficient alternative to prevent testis deltamethrin toxic effects.

\subsubsection{Oat lipids: polar lipids}

Lipids from oats are a heterogeneous mixture of acyl lipids and unsaponifiable components. Neutral lipids are mainly made up of triacylglycerols and account for 50-60\% of total oat lipids ${ }^{77)}$. Kaimainen et $a l{ }^{78)}$ indicated that Avena sativa seeds oil is also rich in polar lipids (glycolipids and phospholipids) which can amount to $34 \%$. This polar lipid fraction is characterized and proven to be useful 


\section{N. Ben Halima, R. Ben Saad and B. Khemakhem et al.}

as a potential oil/water emulsifier because of its amphiphilic structure. Moreover, phospholipids are known to be essential to the establishment of body cells and considered as antioxidants $^{79-81)}$. Oat phospholipids fraction is estimated to be $5-26 \%$ of total lipids ${ }^{61,82,83)}$. Regarding the composition of this lipid class, for example, Price and Parsons ${ }^{84)}$ found that L- $\alpha$-phosphatidylethanolamine(PE), L- $\alpha$-phosphatidylcholine (PC), and L- $\alpha$-lysophosphatidylcholine(lyso-PC) were the most abundant of all tested cereal grains. On the other hand, Sahasrabudhe ${ }^{83)}$ determined some phospholipids proportion in six oat cultivars with $29.9 \%$ PC (the most abundant), 20.4\% L- $\alpha$-lysophosphatidylethanol-amine (lysoPE), 14.8\% PE, 9.5\% L- $\alpha$-phosphatidylglycerol(PG), $3.9 \%$ L- $\alpha$-phosphatidylinositol (PI), and $3.2 \%$ L- $\alpha$-phosphatidylserine (PS). In fact, using high-performance scattering detector (HPLC-ELSD), Aro et al. ${ }^{85)}$ found the same PC content. Also, Doehlert et $a l^{86)}$ characterized the polar lipids fraction from oat kernels by HPLCELSD.

Montealegre et $a l .{ }^{77)}$ determined different phospholipids in Romanian oat samples using high-performance liquid chromatography combined with an evaporative light scattering detector which led to establish that PE was the most representative phospholipid in the entire analyzed oat samples. Montealegre et al. ${ }^{77)}$ also used high-performance liquid chromatography combined with electrospray ionization mass spectrometry analysis, and results showed that C16:0, C16:1, C18:0, C18:1, C18:2, C18:3, C20:0 and C20:1 were the fatty acids bound to the glycerol backbone. Finally, they used also first-preparative TLC and gas chromatography to demonstrate that LA (C18:2) was the main fatty acid of the phospholipid fraction in all the tested samples.

The molecular species of membrane phospholipids of spring oat (Avena sativa L. cv Ogle) was described by Uemura and Steponkus ${ }^{87)}$. These authors found that the plasma membrane lipid composition which was isolated from oat leaves contained predominately phospholipids (28.8 mol\% of the total lipids). They noted also that after 4 weeks of cold acclimation, the proportion of phospholipids increased significantly in oat (from 28.8 to $36.8 \mathrm{~mol} \%$ ) as a result of increases in the proportions of PC and PE as well as the relative proportions of di-unsaturated species increased after the cold acclimation.

\subsubsection{Oat lipids: lipolytic enzymes}

Oat lipolytic enzymes were identified and measured by several authors ${ }^{58,88-92)}$. Widhe and Onselius ${ }^{93)}$ recognized that Avena sativa L. lipase is potentially more active than other cereal grains such as barley, wheat, and rye. Oats also contain promising types of phospholipases such as phospholipase D or phospholipases C. Several reports ${ }^{94-99)}$ highlighted the importance of such enzymes.

\subsection{Carbohydrates: fiber and starch}

The dietary fibers in general are well documented and recognized to be proponents for commercial applications $^{100)}$. Several studies ${ }^{101-103)}$ identified that oat $\beta$-glucan content falls roughly within $2.5-8.3 \%$ of dry grain. In addition, $\beta$-glucan polydispersity ${ }^{104)}$ such as polymer molar masses distribution and polymerization degrees were interesting because the higher-molecular-weight components were highlighted to be biologically beneficial and effective. Report of Lazaridou and Biliaderis ${ }^{105)}$ proved the significance of the molecular weight of $\beta$-glucan polydispersity covering the range of $65-3100 \mathrm{kDa}$. Oat $\beta$-D-glucans are extracted and characterized for industrial utilization ${ }^{106)}$.

Wang and Ellis ${ }^{107)}$ illustrated the physico-chemical characteristics of oat $\beta$-glucan and its effect on blood-glucose and cholesterol-lowering properties. In fact, the potent factor that lowers human cholesterol and postprandial glycaemia is mainly $\beta$-glucan which is a soluble dietary fiber. This bioactive component exists in oats and it is responsible for oat beneficial metabolic effects. To this end, Zhang et $a l .{ }^{108)}$ provided an insight into oat $\beta$-glucan which is beneficial to the digestive system by increasing ATPases activity and the energy charge in the rats' small intestine. The properties and structure of oat $\beta$-glucan vary among oat varieties and are influenced by environmental conditions. Moreover, analysis and extraction methods would also affect oat $\beta$-glucan variation ${ }^{107)}$.

Obviously, the most abundant grain component is starch in most oat cultivars (55-60\% of starch in the oat grain $)^{5,28,62,63)}$. Starch is known as a storage polysaccharide present in the tubers, seeds, etc. of various plants, and consists of two components, amylose and amylopectin (Fig. 2 ${ }^{109)}$. Amylose is a linear glucose polymer with $\alpha-1,4$ linkages, whereas amylopectin is a branched polymer in which linear chains of $\alpha-1,4$ glucose residues are interlinked by $\alpha-1,6$ linkages (Fig. 2).

Oat starch has typical gelatinization characteristics and, when cooling, develops unusually high viscosity ${ }^{28)}$. Compared with the other cereal starches, the cooled oat starch is less firm, easily more digestible, more elastic, more adhesive, clearer and also less susceptible to retrogradation $^{110)}$. Oat starch can contain about 25-30\% amylase. Amylases are a class of hydrolases that can specifically cleave the O-glycosidic bonds in starch. In fact, they are widely distributed in animals, microbes and plafigplants, they play a significant role in seed germination and maturation and would be promising catalysts in many potential applications ${ }^{111,112)}$ compared with those from animal or microbe sources.

The use of starch-converting enzymes (Fig. 3) is the basis of several industrial processes such as maltodextrin and modified starch production, or glucose and fructose syrups preparation; they are also used as laundry and porcelain detergents or as anti-staling agents in baking, bread making 


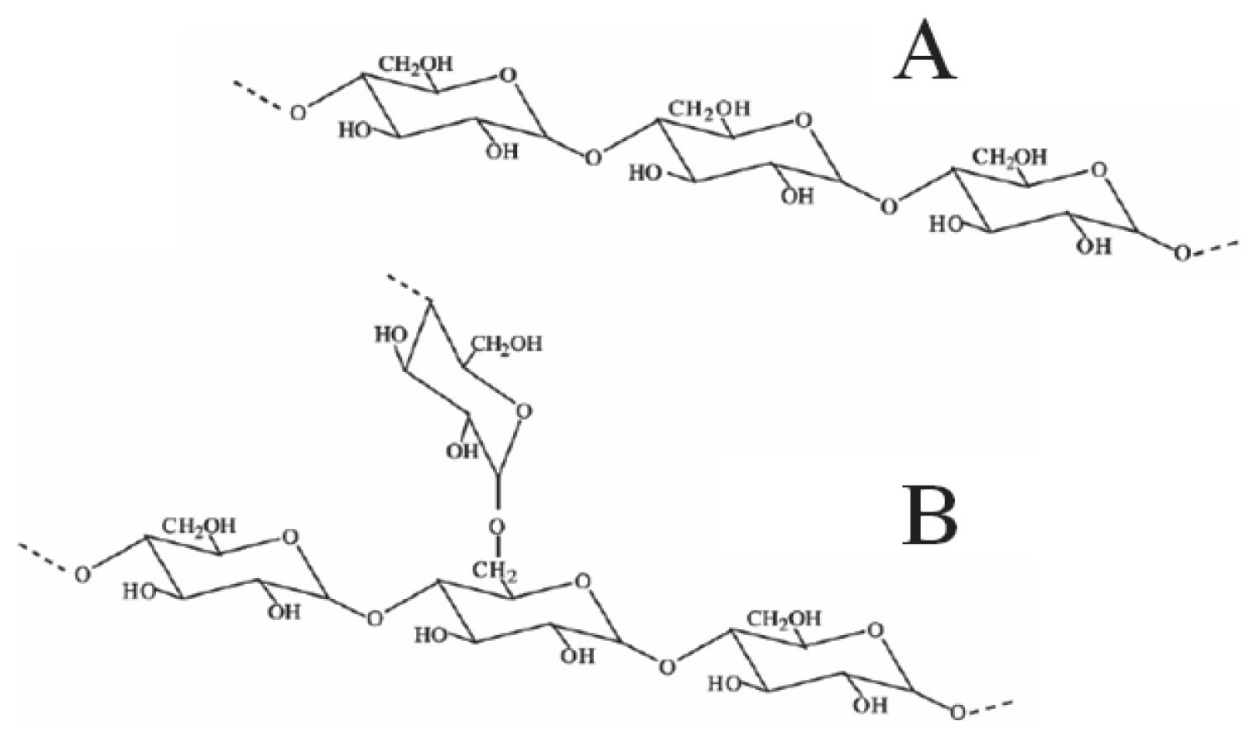

Fig. 2 The structure of the two starch polymers: A: Amylose and B: Amylopectin ${ }^{109)}$.

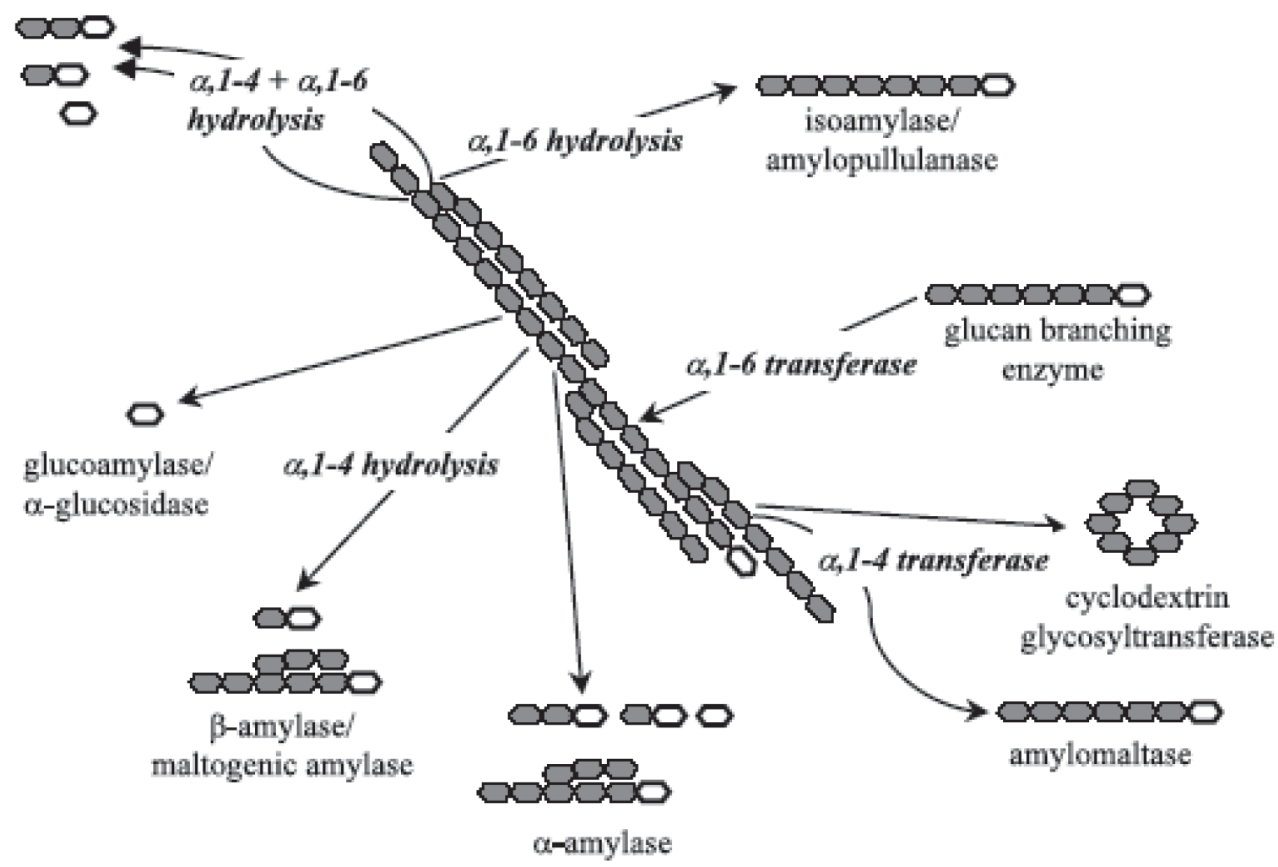

Fig. 3 The different enzymes involved in the degradation of starch. The open ring structure symbolizes the reducing end of a polyglucose molecule ${ }^{113)}$.

and brewing ${ }^{109,113)}$. Currently, these enzymes account for about $30 \%$ of the world's enzyme production ${ }^{113)}$.

Recently, Ben Halima et al. ${ }^{114)}$ showed the beneficial impact of oat amylase on bread properties. In fact, in their report, statistical approaches were employed for the extraction optimization of amylolytic activity from oat (Avena sativa)seeds. The application of the response surface methodology allows determining a set of optimal conditions for this enzyme extraction. Its maximum activity is at $\mathrm{pH}$ 5.6 and at $55^{\circ} \mathrm{C}$. Besides, they studied the incorporation of the optimised oat extract into bread formulation which re- vealed an improvement in the sensory quality and textural properties of fresh and stored bread. Three-dimensional elaborations of confocal laser scanning microscopy (CLSM) images were performed on the crumb of different breads to evaluate the influence of oat amylase activity on microstructure. Results showed improved baking characteristics as well as an overall microscopic and macroscopic appearance $^{114)}$.

Moreover, the aqueous oat extract is a mixture of a multitude of biomolecules exhibiting either amylolytic activity ${ }^{115)}$ or other types of enzymes, in particular chitinase. 
<smiles>[R2]c1c([R1])c2c(c(C)c1O)OC(C)(CCCC(C)CCCC(C)CCCC(C)C)CC2</smiles><smiles>[R2]c1c(C)c2c(c([R2])c1O)CCC(C)(CC/C=C(/C)CC/C=C(\C)CCC=C(C)C)O2</smiles>

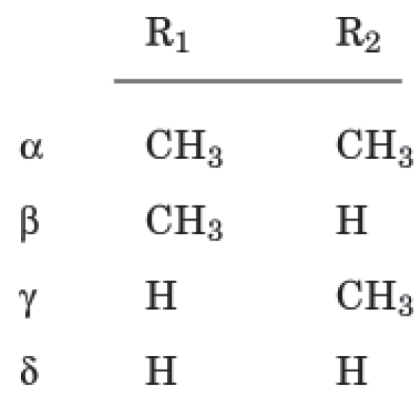

Fig. 4 Structures of tocols:(a) Tocopherols; (b) Tocotrienols ${ }^{121)}$.

Indeed, Sørensen et al. ${ }^{116)}$ showed that oat seed extract is enriched in class I chitinase which acts as an antifungal, especially against Penicillium roqueforti, a major contaminating species in industrial food processing and, hence, oat extract could be used directly on rye bread to prevent $P$. roqueforti colonies formation ${ }^{116)}$. They also found that, compared with wheat, barley and rye seed extracts, class 1 chitinase in oat seed extract is at least ten times more abundant and highly more antifungal toward $P$. roquefort $i$ than the other cereal seed extracts tested.

\subsection{Oat: antioxidant components}

Oats are a source of natural antioxidants ${ }^{117-120)}$, the most abundant of which in Avena sativa L. are tocols (vitamin E), phenolic compounds, phytic acid, avenanthramides as well as sterols and flavonoids ${ }^{121)}$.

\subsubsection{Tocols}

Tocols (tocopherols, tocotrienols, vitamin E, etc.) are lipid-soluble compounds and represent the natural antioxidants in grains ${ }^{122)}$. In fact, tocols are composed of four homologues of tocotrienol and tocopherol(Fig. 4) which differ in position and number of methyl groups on the chroman ring structure ${ }^{121)}$. Thus, they are distinctive in their biologi- cal activities particularly their antioxidant activity ${ }^{123,124)}$. The major tocols in oats are $\alpha$-tocotrienol followed by $\alpha$-tocopherol ${ }^{125)}$ which, combined, account for 86 to $91 \%$ of total tocols ${ }^{121)}$. Tocotrienols have more ability as free radical scavengers than tocopherols ${ }^{126)}$. Vitamin $\mathrm{E}$ is a lipophilic antioxidant present in oats. It is a generic term for entities displaying tocopherol biological activity. Indeed, there are eight tocols with vitamin E activity in plants ${ }^{121}$. In general, these compounds exhibit a biological activity from their ability to donate phenolic hydrogen atoms to free radicals, which allows the breaking of destructive chain reactions ${ }^{127)}$. Intrinsically, tocols could reduce the serum cholesterol concentration and also have the ability to inhibit the growth of cancer cells ${ }^{128)}$. Tocols concentration in oats is significantly affected by location and genotype $^{128)}$. For example, total tocol concentrations in the study of 12 oat genotypes grown at three locations in the U.S.A. ranged from 19.0 to $30.3 \mathrm{mg} / \mathrm{kg}^{128)}$. However, in another survey of 13 oat genotypes mostly European and grown in Hungary, total tocol concentrations ranged from 15 to $48 \mathrm{mg} / \mathrm{kg}^{129)}$.

2.4.2 Avenanthramides

Avenanthramides are phenolic compounds consisting of 


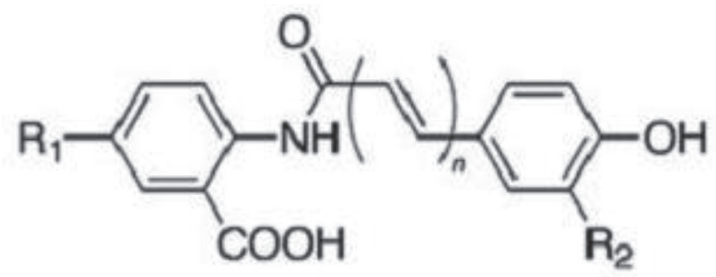

Avenanthramide $\mathrm{A}: \mathrm{R}_{1}=\mathrm{OH}, \mathrm{R}_{2}=\mathrm{H}, n=1$

B : $\mathrm{R}_{1}=\mathrm{OH}, \mathrm{R}_{2}=\mathrm{OCH}_{3}, n=1$

$C: \mathrm{R}_{1}=\mathrm{OH}, \mathrm{R}_{2}=\mathrm{OH}, n=1$

$D: \mathrm{R}_{1}=\mathrm{H}, \mathrm{R}_{2}=\mathrm{H}, n=\mathbf{1}$

$\mathrm{L}: \mathrm{R}_{1}=\mathrm{OH}, \mathrm{R}_{2}=\mathrm{H}, n=2$

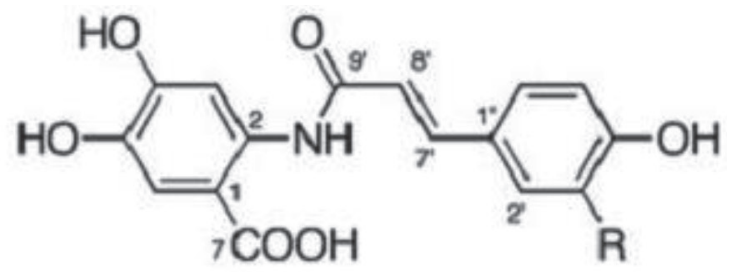

$1: \mathrm{R}=\mathrm{OH}$

$2: \mathrm{R}=\mathrm{H}$

3: $\mathrm{R}=\mathrm{OCH}_{3}$

Fig. 5 Chemical structures of avenanthramides ${ }^{132)}$.

Table 3 Concentrations of some organic compounds (Phenolic acids and aldehydes) present in oat groats and hulls, $\mathrm{mg} / \mathrm{kg}^{121)}$.

\begin{tabular}{|c|c|c|c|c|c|c|}
\hline \multirow[b]{2}{*}{ Compound } & \multicolumn{4}{|c|}{ Groats, free acid } & \multicolumn{2}{|c|}{ Hulls, free acid } \\
\hline & $\begin{array}{l}\text { Sosulski } \\
\text { et al. }{ }^{141)}\end{array}$ & $\begin{array}{l}\text { Xing and } \\
\text { White }^{142)}\end{array}$ & $\begin{array}{l}\text { Dimberg } \\
\text { et al. }{ }^{143)}\end{array}$ & $\begin{array}{l}\text { Emmons and } \\
\text { Peterson }{ }^{144)}\end{array}$ & $\begin{array}{l}\text { Xing and } \\
\text { White }^{142)}\end{array}$ & $\begin{array}{l}\text { Emmons and } \\
\text { Peterson }^{144)}\end{array}$ \\
\hline Caffeic acid & 1.0 & 16.8 & 2.2 & 2.4 & & 0.9 \\
\hline p-Coumaric acid & 0.7 & 44.9 & 1.6 & 0.9 & 59.7 & 9.7 \\
\hline Gallic acid & & & & 1.3 & & 0.6 \\
\hline Ferulic acid & 2.4 & 147.2 & 2.3 & 1.2 & 142.3 & 1.7 \\
\hline p-Hydroxybenzoic acid & 0.7 & 3.5 & & & 50.0 & \\
\hline p-Hydroxybenzaldehyde & & & 0.9 & 0.3 & & 7.7 \\
\hline p-Hydroxyphenylacetic acid & 0.4 & 0.6 & & & 4.6 & \\
\hline Protocatechuic acid & 0.5 & & & 0.7 & & 2.1 \\
\hline Sinapic acid & $\operatorname{tr}$ & & & 0.5 & 5.6 & 0.6 \\
\hline Vanillic acid & 0.7 & 16.1 & 1.2 & 1.6 & 24.3 & 4.0 \\
\hline Vanillin & & 3.4 & 2.3 & 1.0 & 54.2 & 6.3 \\
\hline
\end{tabular}

hydroxycinnamic acid amides and hydroxyanthranilic acids (Fig. 5). They are secondary metabolites found in oat (Avena sativa) groats and hulls ${ }^{130}$. There are at least 20 different phenolic conjugates with anthranilic acid derivatives which are present in oats, but their chemical structures have not been fully identified ${ }^{131)}$. Pihlava $e t$ al. ${ }^{126)}$ estimated that the amount of avenanthramides in grains ranges from $2 \mathrm{mg} / \mathrm{kg}$ to $53 \mathrm{mg} / \mathrm{kg}$.

Ishihara et al. ${ }^{132)}$ identified new series of avenanthramides in the methanol extract of oat seeds. By chromato- graphic tools, they detected and purified three compounds, 1,2 , and 3 , which are eluted at the retention times similarly to avenanthramides. In fact, these three compounds are suggested to be amides of 4,5-dihydroxyanthranilic acid with caffeic, $p$-coumaric, and ferulic acids, amounting to 16.5-26.9\% of corresponding avenanthamides with 5-hydroxyanthranilic acid, respectively, as shown by LC-MS/MS analysis with multiple reaction monitoring.

Avenanthramides play a major role as potential antioxidants $^{133)}$. Peterson et al. ${ }^{134)}$ investigated their anti-oxidant 
activity using in vitro systems such as the reaction with the free radical 2,2-diphenyl-1-picrylhydrazyl (DPPH) or the inhibition of $\beta$-carotene bleaching. Avenanthramides are also considered to be phytoalexins in oat leaves as they display an anti-fungal activity ${ }^{132}$ and their synthesis can be induced by various factors such as either pathogen-related infection $^{135-137)}$ or elicitors treatment ${ }^{138)}$. On the other hand, avenanthramides exhibit an anti-atherogenic, antiinflammatory and anti-itching activity of the skin ${ }^{139,140)}$. They have been shown to inhibit the production of pro-inflammatory cytokines, the adhesion of monocyte cells to aortic endothelial cell monolayers, and the expression of adhesion molecules ${ }^{139)}$.

2.4.3 Other antioxidants: organic acids, sterols, flavonoids 2.4.3.1 Organic acids

A number of organic acids such as p-coumaric acid, caffeic acid, ferulic acid, $p$-hydroxybenzoic acid, vanillic acid, etc. have been reported in oat groats and hulls ${ }^{121)}$, as shown in Table 3. Previous studies ${ }^{141-144)}$ indicated differences in these compounds content very likely due to the extraction methods.

Oats also contain significant amounts of phytic acid ${ }^{121)}$ which exhibits antioxidant functions ${ }^{145}$. Several works ${ }^{146-149)}$ on phytic acid in oat revealed variation in its concentration. Saastamoinen et al. ${ }^{146)}$ reported that oat phytic acid concentration averaged 5.6 to $8.7 \mathrm{mg} / \mathrm{g}$ in five cultivars grown at four locations for 2 years in Finland, whereas, a groat phytic acid concentration from four oat cultivars grown at three locations in Wisconsin, U.S.A. for 4 years averaged $12.7 \mathrm{mg} / \mathrm{g}^{148}$. Besides, phytic acid concentration in a whole oat grain was about $11.4 \mathrm{mg} / \mathrm{g}$ according to a study of Larsson and Sandberg ${ }^{146}$. In fact, phytic acid concentration is affected by environmental factors such as available soil $\mathrm{P}^{147,150)}$

\subsubsection{Sterols}

Oats also comprise a number of sterols some of which can exhibit an antioxidant activity ${ }^{121)}$. Singh et al. ${ }^{28)}$ indicated that acylated sterylglycosides, sterylglycosides and steroidal saponins can be found in oat leaves. The major sterol in oat is $\beta$-sitosterol with $\Delta^{5}$-avenasterol and $\Delta^{7}$ avenasterol (Fig. 6) also present in significant quantities ${ }^{151}$. 2.4.3.3 Flavonoids

Oats also contain flavonoids (Fig. 7). Recently, Zhang et $a l .{ }^{152)}$ isolated fifteen chemical constituents identified as flavonoids from Avena sativa bran, nine of which were isolated from Avena sativa Linn. for the first time and identified as kaempferol 3-O-(2", 3" -di-E-p-coumaroyl)$\alpha$-L-rhamnopyranoside (1), kaempferol 3-O- (3" -E-p-coumaroyl) - $\alpha$-L rhamnopyranoside (2), kaempferol 3-O- (2" -OE-p-coumaroyl)- $\beta$-D-glucopyranoside (3), kaempferol 3-O$\beta$-D-glucopyranoside (4), kaempferol 7-O- $\alpha$-Lrhamnopyranoside (5), linarin (6), tilianin (7), myricitrin (8) and quercitrin $(9)^{152)}$.<smiles>C/C=C(\CCC(C)C1CCC2C3CC=C4CC(O)CCC4(C)C3CCC12C)C(C)C</smiles><smiles>C/C=C(\C)CCC(C)C1CCC2C3=CCC4CC(O)CCC4(C)C3CCC21C</smiles>

Fig. 6 Structures of the three most common oat sterols $^{121)}$.

\section{Oats: prevention of disease}

Antioxidants have a high potential to prevent diseases. Tocotrienols are among antioxidants having cholesterollowering properties in humans and experimental animals ${ }^{41}$. Moreover, oat oil was recently proven to promote the excretion of faecal lipids in hypercholesterolemic rats and, thus, lower plasma and liver cholesterol concentrations ${ }^{153)}$.

Several studies focused on oats as a therapeutical agent as well as its instrumental antioxidant system ${ }^{154)}$ to heal such acute diseases as colon tumor ${ }^{155)}$ and hepatic steato$\operatorname{sis}^{156)}$.

Oats consumption is associated with a reduced risk of chronic ailments such as type 2 diabetes and cardiovascular diseases (CVD) ${ }^{157)}$. In fact, Thies et al. ${ }^{157)}$ described these effects through long-term intervention studies revealing a reduction in CVD risk markers.

Thongoun et al. ${ }^{158)}$ confirmed that oat $\beta$-glucan considerably reduced blood cholesterol levels in Thai hypercholesterolemic adults. Thus, following daily oatmeal consumption (3 g of soluble fiber beta glucan), reduced total 
<smiles>[R]c1cc(-c2oc3c([R2])c(O)c([R])c(O)c3c(=O)c2[R1])cc([R8])c1O</smiles>

\begin{tabular}{llllll} 
& $\mathrm{R}_{1}$ & $\mathrm{R}_{2}$ & $\mathrm{R}_{3}$ & $\mathrm{R}_{4}$ & $\mathrm{R}_{5}$ \\
\cline { 2 - 6 } Apigenin & $\mathrm{H}$ & $\mathrm{H}$ & $\mathrm{H}$ & $\mathrm{H}$ & $\mathrm{H}$ \\
Apigenin-6-C-glucoside & $\mathrm{H}$ & $\mathrm{H}$ & $\mathrm{Glu}$ & $\mathrm{H}$ & $\mathrm{H}$ \\
Apigenin-8-C-glucoside & $\mathrm{H}$ & $\mathrm{Glu}$ & $\mathrm{H}$ & $\mathrm{H}$ & $\mathrm{H}$ \\
Luteolin & $\mathrm{H}$ & $\mathrm{H}$ & $\mathrm{H}$ & $\mathrm{H}$ & $\mathrm{OH}$ \\
Tricin & $\mathrm{H}$ & $\mathrm{H}$ & $\mathrm{H}$ & $\mathrm{OCH}_{3}$ & $\mathrm{OCH}_{3}$ \\
Kaempferol & $\mathrm{OH}$ & $\mathrm{H}$ & $\mathrm{H}$ & $\mathrm{H}$ & $\mathrm{H}$ \\
Kaempferol-3-0-rutinoside & $\mathrm{O}-r u t$ & $\mathrm{H}$ & $\mathrm{H}$ & $\mathrm{H}$ & $\mathrm{H}$ \\
Quercetin & $\mathrm{OH}$ & $\mathrm{H}$ & $\mathrm{H}$ & $\mathrm{H}$ & $\mathrm{OH}$ \\
Quercetin-3-o-rutinoside & $\mathrm{O}$ O-rut & $\mathrm{H}$ & $\mathrm{H}$ & $\mathrm{H}$ & $\mathrm{OH}$
\end{tabular}

Fig. 7 Structures of flavonoids identified from oat ${ }^{121)}$.

cholesterol and LDL-cholesterol levels by 5 and $10 \%$, respectively. Furthermore, these levels were significantly lower than those observed with rice consumption ${ }^{158)}$.

Oats are unique in providing vital nutrients (unsaturated TAG, complex lipids, resistant starch, phenolic compounds, etc.) for the gut microbiota ${ }^{159)}$. Therefore, they contribute to a healthy human gut microbiome which plays a fundamental role in ensuring intestinal functions and preventing bowel diseases ${ }^{159-161)}$.

A systematic literature review describing intervention studies investigated oats effects on bowel disease ${ }^{160)}$. Results showed that the consumption of uncontaminated oats up to $100 \mathrm{~g} / \mathrm{d}$ could be tolerated by most patients with coeliac disease, an autoimmune disorder of the gastrointestinal tract and, thus, oats can be added to a gluten-free diet for these patients.

Several recent reports ${ }^{162-165)}$ suggested that the consumption of oats attenuated hyperglycemia and diabetes, prevented obesity, abdominal fat and improved liver function by inhibiting lipogenesis in animal models as well as in a clinical trials. Consequently, a daily oat supplement can act as an effective adjuvant for the treatment of metabolic disorders in humans.

In a recent experiment, Boffetta et al. ${ }^{166)}$ focused on the effectiveness of oats consumption on epidemiological studies including cancer risk and overall mortality. Results provided weak evidence of oats protective effect on cancer risk and overall mortality; however, further experiments should be conducted in the future.

\section{Conclusion and open directives}

Oats (Avena sativa L.) are unique compared with other cereals thanks to the high quality of their composition, especially lipids, bioactive components and antioxidant systems. They have been globally recognized as relevant for a wide range of applications namely in pharmacology, medicine and food industries, which explains their inclusion in the British Herbal Pharmacopoeia ${ }^{167)}$. Therefore, they constitute useful plants for a healthier world, and future investigations on their organism are required for a better and deeper understanding of their genome.

Huang et $a l .{ }^{168)}$ dealt with the utility of genomic approaches, especially genotyping-by-sequencing (GBS) to provide additional information on oat breeding. In addition, the development of single nucleotide polymorphism(SNP) on hexaploid oats using high-throughput 454 sequencing technology ${ }^{169)}$ favours the understanding of complex genomes. Moreover, ESTs (expressed sequence tags)are useful tools contributing to the identification of genes from oats $^{170)}$ thus improving knowledge of the full oat genome.

\section{ACKNOWLEDGMENTS}

The authors thank the Tunisian Ministry of Higher Education, Scientific Research and Technology for their facilities.

\section{REFERENCES}

1) Baublis, A.; Decker, E. A.; Clydesdale, F. M. Antioxidant effects of aqueous extracts from wheat based ready to eat breakfast cereals. Food Chem. 68, 1-6 (2000).

2) Bennett, M. D.; Smith, J. B. Nuclear DNA amounts in angiosperms. Philos. Trans. R. Soc. Lond. B 274, 227-274 (1976).

3) Flander, L.; Salmenkallio-Marttila, M.; Suortti, T.; Autio, K. Optimization of ingredients and baking process for improved whole meal oat bread quality. $L W T$ Food Sci. Technol. 40, 860-870 (2007).

4) Grimberg, A. Preferred carbon precursors for lipid labelling in the heterotrophic endosperm of developing oat (Avena sativa L.) grains. Plant Physiol. Biochem. 83, 346-355 (2014).

5) Banas, A.; Dexbski, H.; Banas, W.; Heneen, W. K.; Dahlqvist, A.; Bafor, M.; Gummeson, P. O.; Marttila, S.; Ekman, A.; Carlsson, A. S.; Stymne, S. Lipids in grain 


\section{N. Ben Halima, R. Ben Saad and B. Khemakhem et al.}

tissues of oat (Avena sativa): differences in content, time of deposition, and fatty acid composition. $J$. Exp. Botany 58, 2463-2470 (2007).

6) Liu, K. Comparison of lipid content and fatty acid composition and their distribution within seeds of 5 small grain species. J. Food Sci. 76, C334-C342 (2011).

7) Barthole, G.; Lepiniec, L.; Rogowsky, P. M.; Baud, S. Controlling lipid accumulation in cereal grains. Plant Sci. 185-186, 33-39 (2012).

8) Ekman, A.; Hayden, D. M.; Dehesh, K.; Bulow, L.; Stymne, S. Carbon partitioning between oil and carbohydrates in developing oat (Avena sativa L.) seeds. J. Exp. Botany 59, 4247-4257 (2008).

9) Särkijärvi, S.; Saastamoinen, M. Feeding value of various processed oat grains in equine diets. Livestock Sci. 100, 3-9 (2006).

10) Food and Agriculture Organization of the United Nations FAOSTAT. http://faostat.fao.org/(accessed on April 2014).

11) Sánchez-Martín, J.; Rubiales, D.; Flores, F.; Emeran, A. A.; Shtaya, M. J. Y.; Sillero, J. C.; Allagui, M. B.; Prats, E. Adaptation of oat (Avena sativa) cultivars to autumn sowings in Mediterranean environments. Field Crops Res. 156, 111-122 (2014).

12) Butt, M. S.; Tahir-Nadeem, M.; Khan, M. K. I.; Shabir, R.; Butt, M. S. Oat: unique among the cereals. Eur. J. Nutr. 47, 68-79(2008).

13) Welch, R. W. Oats in human health and nutrition. In: Welch RW(ed.), The Oat Crop: Production and Utilization, London: Chapman and Hall, pp. 433-479 (1995).

14) USDA Nutrient Database - Release 25, http:// ndb. nal.usda.gov/(accessed on April 2013).

15) United States Department of Agriculture \& Foreign Agricultural Service. Grain: world markets and trade, http://apps.fas.usda.gov/psdonline/circulars/production.pdf(accessed on 18 May 2014).

16) Hammami, I.; Allagui, M. B.; Chakroun, M.; El-Gazzeh, M. Agronomic Characterization of Tunisian Spontaneous Oat Accessions Resistant to Oat Crown Rust and Potential in Plant Breeding. Tun. J. Plant Protec. 3, 1-9 (2008).

17) Givens, I.; Davies, T. W.; Laverick, R. M. Effect of variety, nitrogen fertiliser and various agronomic factors on the nutritive value of husked and naked oats grain. Anim. Feed Sci. Technol. 113, 169-181 (2004).

18) Stewart, D.; McDougall, G. Oat agriculture, cultivation and breeding targets: implications for human nutrition and health. Br. J. Nutr. 112, S50-S57 (2014).

19) Frey, K. Genetic responses of oat genotypes to environmental factors. Field Crops Res. 56, 183-185 (1998).
20) Jackson, E. W.; Obert, D. E.; Avant, J. B.; Harrison, S. A.; Chong, J.; Carson, M. L.; Bonman, J. M. Quantitative trait loci in the Ogle/TAM O-301 oat mapping population controlling resistance to Puccinia coronata in the field. Phytopathology 100, 484-492(2010).

21) Roderick, H. W.; Jones, E. R. L.; Sebesta, J. Resistance to oat powdery mildew in Britain and Europe: a review. Ann. Appl. Biol. 136, 85-91 (2000).

22) Jin, H.; Domier, L. L.; Kolb, F. L.; Brown, C. M. Identification of quantitative loci for tolerance to barley yellow dwarf virus in oat. Phytopathology 88, 410415 (1998).

23) Li, Y.; Wang, Z.; Beier, R. C. T-2 toxin, a trichothecene mycotoxin: review of toxicity, metabolism, and analytical methods. J. Agric. Food Chem. 59, 3441-3453 (2011).

24) European Commission, Commission recommendation on the prevention and reduction of Fusarium toxins in cereals and cereal products: principles for the prevention and reduction of Fusarium toxin contamination in cereals, Official J. Eur. Union 583, 234-237 (2006).

25) Edwards, S. G.; Imathiu, S. M.; Ray, R. V.; Back, M.; Hare, M. C. Molecular studies to identify the Fusarium species responsible for HT-2 and T-2 mycotoxins in UK oats. Int. J. Food Microbiol. 156, 168-175 (2012).

26) Tiwari, N.; Awasthi, P. Effect of different processing techniques on nutritional characteristics of oat (Avena sativa) grains and formulated weaning mixes. $J$. Food Sci. Technol. 51, 2256-2259 (2014).

27) Decker, E. A.; Rose, D. J.; Stewart, D. Processing of oats and the impact of processing operations on nutrition and health benefits. Br. J. Nutr. 112, S58-64 (2014).

28) Singh, R.; De, S.; Belkheir, A. Avena sativa (Oat), A Potential Neutraceutical and Therapeutic Agent: An Overview. Crit. Rev. Food Sci. Nutr. 53, 126-144 (2013).

29) Lapveteläinen, A.; Aro, T. Protein composition and functionality of high-protein oat flour derived from integrated starch-ethanol process. Cereal Chem. 71, 133-139 (1994).

30) Peterson, D. M. Protein Concentration, Concentration of Protein Fractions, and Amino Acid Balance in Oats. Crop Sci. 16, 663-666(1976).

31) Anderson, O. D. The Spectrum of Major Seed Storage Genes and Proteins in Oats (Avena sativa). PLoS One 9, e83569 (2014).

32) Bewley, J. D.; Bradford, K. J.; Hilhorst, H. W. M.; Nonogaki, H. Seeds: Physiology of Development, Germination and Dormancy. Springer 400 (2012).

33) Loponen, J.; Laine, P.; Sontag-Strohm, T.; Salovaara, $\mathrm{H}$. Behavior of oat globulins in lactic acid fermenta- 
tion of oat bran. Eur. Food Res. Technol. 225, 105110 (2007).

34) Konak, U. I.; Ercili-Cura, D.; Sibakov, J.; SontagStrohm, T.; Certel, M.; Loponen, J. $\mathrm{CO}_{2}$-defatted oats: Solubility, emulsification and foaming properties. $J$. Cereal Sci. 60, 37-41 (2014).

35) Sibakov, J.; Myllymäki, O.; Holopainen, U.; Kaukovirta-Norja, A.; Hietaniemi, V.; Pihlava, J. M.; Poutanen, K.; Lehtinen, P. Lipid removal enhances separation of oat grain cell wall material from starch and protein. $J$. Cereal Sci. 54, 104-109 (2011).

36) Smith, D. M. Measurement of functional properties: overview of protein functionality testing. In: Wrolstad, R. E.; Acree, T. E.; Decker, E. A.; Penner, M. H.; Reid, D. S.; Schwartz, S. J.; Shoemaker, C. F.; Smith, D. M.; Sporns, P. (Eds.), Current Protocols in Food Analytical Chemistry. John Wiley \& Sons Inc. 266-269 (2003).

37) Meng, G.; Ma, C. Y. Characterization of globulin from Phaseolus angularis(red bean). Int. J. Food Sci. Technol. 37, 687-695(2002).

38) Kurtz, E. S.; Wallo, W. Colloidal oatmeal: history, chemistry and clinical properties. J. Drugs Dermatol. 6, 167-170 (2007).

39) Sur, R.; Nigam, A.; Grote, D.; Liebel, F.; Southall, M. D. Avenanthramides, polyphenols from oats, exhibit anti-inflammatory and anti-itch activity. Arch. Dermatol. Res. 300, 569-574(2008).

40) Frey, K. J.; Holland, J. B. Nine cycles of recurrent selection for increased grain-oil content in oat. Crop Sci. 39, 1636-1641 (1999).

41) Peterson, D. M.; Wood, D. F. Composition and Structure of High-Oil Oat. J. Cereal Sci. 26, 121-128 (1997).

42) Youngs, V. L. Oat lipids. Cereal Chem. 55, 591-597 (1978).

43) Leng, E. R. Predicted and actual responces during long-term selection for chemical composition in maize. Euphytica 10, 368-378(1961).

44) White, D. A.; Fisk, I. D.; Gray, D. A. Characterisation of oat (Avena sativa L.) oil bodies and intrinsically associated E-vitamers. J. Cereal Sci. 43, 244-249 (2006).

45) Martinez, M. F.; Arelovich, H. M.; Wehrhahne, L. N. Grain yield, nutrient content and lipid profile of oat genotypes grown in a semiarid environment. Field Crops Res. 116, 92-100 (2010).

46) Zhou, M. X.; Glennie Holmes, M.; Robards, K.; Helliwell, S. Fatty Acid Composition of Lipids of Australian Oats. J. Cereal Sci. 28, 311-319 (1998).

47) Heneen, W. K.; Banas, A.; Leonova, S.; Carlsson, A. S.; Marttila, S.; Debski, H.; Stymne, S. The distribution of oil in the oat grain. Plant Signal Behav. 4, 55-56 (2009).
48) Leonova, S.; Grimberg, A.; Marttila, S.; Stymne, S.; Carlsson, A. S. Mobilization of lipid reserves during germination of oat (Avena sativa L.), a cereal rich in endosperm oil. J. Exp. Botany 61, 3089-3099 (2010).

49) Hsieh, K.; Huang, H. C. Endoplasmic reticulum, oleosins, and oils in seeds and tapetum cells. Plant Physiol. 136, 3427-3434 (2004).

50) Siloto, R. M. P.; Findlay, K.; Lopez-Villalobos, A.; Yeung, E. C.; Nykiforuk, C. L.; Moloney, M. M. The accumulation of oleosins determines the size of seed oil bodies in Arabidopsis. Plant Cell. 18, 1961-1974 (2006).

51) Clarke, N. A.; Wilkinson, M. C.; Laidman, D. L. Lipid metabolism in germinating cereals. In: Barnes PJ, ed. Lipids in cereal technology. London: Academic Press, 57-92 (1983).

52) Graham, I. A. Seed storage oil mobilization. Annual Rev. Plant Biol. 59, 115-142 (2008).

53) Schmid, M.; Simpson, D.; Gietl, C. Programmed cell death in castor bean endosperm is associated with the accumulation and release of a cysteine endopeptidase from ricinosomes. Proceed. Nat. Acad. Sci. USA 96, 14159-14164(1999).

54) Young, T. E.; Gallie, D. R. Regulation of programmed cell death in maize endosperm by abscisic acid. Plant Mol. Biol. 42, 397-414(2000).

55) Fincher, G. B. Molecular and cellular biology associated with endosperm mobilization in germinating cereal grains. Ann. Rev. Plant Physiol. Plant Mol. Biol. 40, 305-346 (1989).

56) Ziegler, P. Carbohydrate degradation during germination. In: Kigel, J.; Galili, G. eds. Seed development and germination. New York: CRC Press 447-474 (1995).

57) Beck, E.; Ziegler, P. Biosynthesis and degradation of starch in higher plants. Ann. Rev. Plant Physiol. Plant Mol. Biol. 40, 95-117 (1989).

58) Kaukovirta-Norja, A.; Wilhelmson, A.; Poutanen, K. Germination: a means to improve the functionality of oat. Agric. Food Sci. 13, 100-112 (2004).

59) Lehtinen, P.; Kiiliainen, K.; Lehtomaki, I.; Laakso, S. Effect of heat treatment on lipid stability in processed oats. J. Cereal Sci. 37, 215-221 (2002).

60) Price, P. B.; Parsons, J. Distribution of lipids in embryonic axis, bran-endosperm, and hull fractions of hulless barley and hulless oat grain. J. Agric. Food Chem. 27, 813-815(1979).

61) Youngs, V. L.; Püskülcü, M.; Smith, R. R. Oat lipids I. Composition and distribution of lipid components in two oat cultivars. Cereal Chem. 54, 803-812 (1977).

62) Welsh, R. W. The chemical composition of oats. In: Welsh, R. W. (ed.), The oat crop, London: Chapman \& Hall, 279-320 (1995).

63) Doehlert, D. C.; McMullen, M. S.; Hammond, J. J. Ge- 


\section{N. Ben Halima, R. Ben Saad and B. Khemakhem et al.}

notypic and environmental effects on grain yield and quality of oat grown in North Dakota. Crop Sci. 41, 1066-1072(2001).

64) Ben Halima, N.; Ben Slima, A.; Moalla, I.; Fetoui, H.; Pichon, C.; Gdoura, R.; Abdelkafi, S. Protective effects of oat oil on deltamethrin-induced reprotoxicity in male mice. Food Funct. 5, 2070-2077 (2014).

65) Leonova, S.; Shelenga, T.; Hamberg, M.; Konarev, A.V.; Loskutov, I.; Carlsson, A. S. Analysis of Oil Composition in Cultivars and Wild Species of Oat (Avena sp.). J. Agric. Food Chem. 56, 7983-7991 (2008).

66) Nebus, J.; Nystrand, G.; Fowler, J.; Wallo, W. A daily oat-based skin care regimen for atopic skin, DERMATITIS, ATOPIC[P1301]. J. Am. Acad. Dermatol. 60, $\mathrm{AB} 67$ (2009).

67) Southall, M.; Pappas, A.; Nystrand, G.; Nebus, J. Oat Oil Improves the Skin Barrier, Johnson \& Johnson Consumer Companies, Inc. (2012).

68) Hansen, H. S.; Jensen, B. Essential function of linoleic acid esterified in acylglucosylceramide and acylceramide in maintaining the epidermal water permeability barrier. Evidence from feeding studies with oleate, linoleate, arachidonate, columbinate and alphalinolenate. Biochim. Biophys. Acta 834, 357-363 (1985).

69) Elias, P. M.; Brown, B. E.; Ziboh, V. A. The permeability barrier in essential fatty acid deficiency: evidence for a direct role for linoleic acid in barrier function. $J$. Invest. Dermatol. 74, 230-233 (1980).

70) Feng, B.; Ma, L.; Yao, J.; Fang, Y.; Mei, Y.; Wei, S. Protective effect of oat bran extracts on human dermal fibroblast injury induced by hydrogen peroxide. $J$. Zhejiang Univ-Sci. B(Biomed. \& Biotechnol.) 14, 97-105(2013).

71) Mulder, W. M. C.; Meinardi, M. M. H. M. Dermatological drugs and topical agents. Chapter 14 Side Effects of Drugs, Annual 25 J.K. Aronson, (ed.), 175-182 (2002).

72) Ben Slima, A.; Ben Ali, M.; Barkallah, M.; Traore, A. I.; Boudawara, T.; Allouche, N.; Gdoura, R. Antioxidant properties of Pelargonium graveolens L'Her essential oil on the reproductive damage induced by deltamethrin in mice as compared to alpha-tocopherol. Lipids Health Dis. 12, 30 (2013).

73) Ismail, M. F.; Mohamed, H. M. Deltamethrin-induced genotoxicity and testicular injury in rats: Comparison with biopesticide. Food Chem. Toxicol. 50, 34213425 (2012).

74) Astiz, M.; Hurtado de Catalfo, G. E.; Garcia, M. N.; Galletti, S. M.; Errecalde, A. L.; de Alaniz, M. J. T.; Marra, C. A. Pesticide-induced decrease in rat testicular steroidogenesis is differentially prevented by lipoate and tocopherol. Ecotoxicol. Environ. Safety 91, 129-138(2013).
75) Hensley, K.; Benaksas, E. J.; Bolli, R.; Comp, P.; Grammas, P.; Hamdheydari, L.; Mou, S.; Pye, Q. N.; Stoddard, M. F.; Wallis, G.; Williamson, K. S.; West, M.; Wechter, W. J.; Floyd, R. A. New perspectives on vitamin E: $\gamma$-tocopherol and carboxyethylhydroxychroman metabolites in biology and medicine. Free Radical Biol. Med. 36, 1-15(2004).

76) Cerolini, S.; Zaniboni, L.; Maldjian, A.; Gliozzi, T. Effect of docosahexaenoic acid and $\alpha$-tocopherol enrichment in chicken sperm on semen quality, sperm lipid composition and susceptibility to peroxidation. Theriogenology 66, 877-886 (2006).

77) Montealegre, C.; Verardo, V.; Gomez-Caravaca, A. M.; García-Ruiz, C.; Marina, M. L.; Caboni, M. F. Molecular Characterization of Phospholipids by High-Performance Liquid Chromatography Combined with an Evaporative Light Scattering Detector, High-Performance Liquid Chromatography Combined with Mass Spectrometry, and Gas Chromatography Combined with a Flame Ionization Detector in Different Oat Varieties. J. Agric. Food Chem. 60, 10963-10969 (2012).

78) Kaimainen, M.; Ahvenainen, S.; Kaariste, M.; Jarvenpaa, E.; Kaasalainen, M.; Salomaki, M.; Salonen, J.; Huopalahti, R. Polar lipid fraction from oat (Avena sativa): characterization and use as an o/w emulsifier. Eur. Food Res. Technol. 235, 507-515(2012).

79) Przybylski, R.; Lee, Y.; Kim, I. Oxidative stability of canola oils extracted with supercritical carbon dioxide. Lebensm.-Wiss Technol. 31, 687-693(1998).

80) Koprivnjak, O.; Majetic, V. M.; Staver, M.; Lovric, A.; Blagovic, B. Effect of phospholipids on extraction of hydrophilic phenols from virgin olive oils. Food Chem. 119, 698-702(2010).

81) Szydlowska-Czerniak, A.; Karlovits, G.; Hellner, G.; Dianoczki, C.; Szlyk, E. Effect of enzymatic and hydrothermal treatments of rapeseeds on quality of the pressed rapeseed oils: PartI: Antioxidant capacity and antioxidant content. Process Biochem. 45, 7-17 (2010).

82) delaRoche, I.; Burrows, V. D.; McKenzie, R. I. H. Variation in lipid composition among strains of oats. Crop Sci. 17, 145-148(1977).

83) Sahasrabudhe, M. R. Lipid composition of oats (Avena sativa L.). J. Am. Oil Chem. Soc. 56, 80-84(1979).

84) Price, P. B.; Parsons, J. G. Lipids of seven cereal grains. J. Am. Oil Chem. Soc. 52, 490-493(1975).

85) Aro, H.; Jarvenpaa, E.; Konko, K.; Huopalahti, R.; Hietaniemi, V. The characterisation of oat lipids produced by supercritical fluid technologies. J. Cereal Sci. 45, 116-119(2007).

86) Doehlert, D. C.; Moreau, R. A.; Welti, R.; Roth, M. R.; McMullen, M. S. Polar lipids from oat kernels. Cereal Chem. 87, 467-474(2010). 
87) Uemura, M.; Steponkus, P. L. A Contrast of the Plasma Membrane Lipid Composition of Oat and Rye Leaves in Relation to Freezing Tolerance. Plant Physiol. 104, 479-496(1994).

88) Sahasrabudhe, M. R. Measurement of Lipase Activity in Single Grains of Oat (Avena sativa L.). J. Am. Oil Chem. Soc. 59, 354-355(1982).

89) Fendri, I.; Ben Saad, R.; Khemakhem, B.; Ben Halima, N.; Gdoura, R.; Abdelkafi, S. Effect of treated and untreated domestic wastewater on seed germination, seedling growth and amylase and lipase activities in Avena sativa L. J. Sci. Food. Agric. 93, 1568-1574 (2013).

90) Mohamed, M. A.; Mohamed, T. M.; Mohamed, S. A.; Fahmy, A. S. Distribution of lipases in the Gramineae. Partial purification and characterization of esterase from Avena fatua. Biores. Technol. 73, 227-234 (2000).

91) Peterson, D. M. Lipase Activity and Lipid Metabolism During Oat Malting. Cereal Chem. 76, 159-163 (1999).

92) Piazza, G. J.; Bilyk, A.; Brower, D. P.; Haas, M. J. The Positional and Fatty Acid Selectivity of Oat Seed Lipase in Aqueous Emulsions. J. Am. Oil Chem. Soc. 69, 978-981 (1992).

93) Widhe, T.; Onselius, T. Lipolysis in doughs made from various cereal flours. Cereal Chem. 26, 393(1949).

94) Pokotylo, I.; Kolesnikov, Y.; Kravets, V.; Zachowski, A.; Ruelland, E. Plant phosphoinositide-dependent phospholipases C: Variations around a canonical theme. Biochimie 96, 144-157 (2014).

95) Pappan, K.; Wang, X. Molecular and biochemical properties and physiological roles of plant phospholipase D. Biochem. Biophys. Acta 1439, 151-166 (1999).

96) Bargmann, B. O.; Munnik, T. The role of phospholipase D in plant stress responses. Curr. Opin. Plant Biol. 9, 515-522 (2006).

97) Pokotylo, I.; Pejchar, P.; Potocky, M.; Kocourková, D.; Krcková, Z.; Ruelland, E.; Kravets, V.; Martinec, J. The plant non-specific phospholipase $\mathrm{C}$ gene family. Novel competitors in lipid signaling. Prog. Lipid Res. 52, 62-79 (2013).

98) Wang, $X$. The role of phospholipase D in signaling cascades. Plant physiol. 120, 645-651 (1999).

99) Huang, C. H.; Crain, R. Phosphoinositide-specific phospholipase $\mathrm{C}$ in oat roots: association with the actin cytoskeleton. Planta 230, 925-933(2009).

100) Elleuch, M.; Bedigian, D.; Roiseux, O.; Besbes, S.; Blecker, C.; Attia, H. Dietary fibre and fibre-rich byproducts of food processing: Characterisation, technological functionality and commercial applications: A review. Food Chem. 124, 411-421 (2011).

101) Lee, C. J.; Horsley, R. D.; Manthey, F. A.; Schwarz, P. B.
Comparisons of $\beta$-glucan content of barley and oat. Cereal Chem. 74, 571-575(1997).

102) Cervantes-Martinez, C. T.; Frey, K. J.; White, P. J. Selection for greater $\beta$-glucan content in oat grain. Crop Sci. 41, 1085-1091 (2001).

103) Newell, M. A.; Asoro, F. G.; Scott, M. P.; White, P. J.; Beavis, W. D.; Jannink, J. L. Genome-wide association study for oat (Avena sativa L.) beta-glucan concentration using germplasm of worldwide origin. Theor. Appl. Genet. 125, 1687-1696(2012).

104) Liu, Y.; White, P. J. Molecular Weight and Structure of Water Soluble $(1 \rightarrow 3)$, $(1 \rightarrow 4)$ - $\beta$-Glucans Affect Pasting Properties of Oat Flours. J. Food Sci. 76, C68C74 (2011).

105) Lazaridou, A.; Biliaderis, C. G. Molecular aspects of cereal $\beta$-glucan functionality: physical properties, technological applications and physiological effects. J. Cereal Sci. 46, 101-118(2007).

106) Ahmad, A.; Anjum, F. M.; Zahoor, T.; Nawaz, H.; Ahmed, Z. Extraction and characterization of $\beta$-Dglucan from oat for industrial utilization. Int. J. Biol. Macromol. 46, 304-309(2010).

107) Wang, Q.; Ellis, P. R. Oat $\beta$-glucan: physico-chemical characteristics in relation to its blood-glucose and cholesterol-lowering properties. Br. J. Nutr. 112, S4S13 (2014).

108) Zhang, P. P.; Hu, X. Z.; Zhen, H. M.; Xu, C.; Fan, M. T. Oat $\beta$-Glucan Increased ATPases Activity and Energy Charge in Small Intestine of Rats. J. Agric. Food Chem. 60, 9822-9827 (2012).

109) Muralikrishna, G.; Nirmala, M. Cereal $\alpha$-amylases - an overview. Carbohyd. Polymers 60, 163-173(2005).

110) Webster, F. H. Whole-grain oats and oat product. In: Whole-Grain Foods in Health and Disease, Marquart, L.; Slavin, J. L.; Fulcher, R. G. (eds.), Amer. Assoc. Cereal Chem., St. Paul, MN, pp. 83-123 (2002).

111) Khemakhem, B.; Fendri, I.; Dahech, I.; Belghuith, K.; Kammoun, R.; Mejdoub, H. Purification and characterization of a maltogenic amylase from Fenugreek (Trigonella foenum graecum) seeds using the Box Benkhen Design(BBD). Ind. Crop. Prod. 43, 334339 (2013).

112) Sharopova, N. R.; Portyanko, V. A.; Sozinov, A. A. Genetics of $\alpha$-Amylases in Hexaploid Oat Species. Biochem. Genetics 36, 171-182 (1998).

113) Van der Maarel, M. J. E. C.; Van der Veen, B.; Uitdehaag, J. C. M.; Leemhuis, H.; Dijkhuizen, L. Properties and applications of starch-converting enzymes of the $\alpha$-amylase family. J. Biotechnol. 94, 137-155 (2002).

114) Ben Halima, N.; Borchani, M.; Fendri, I.; Khemakhem, B.; Gosset, D.; Baril, P.; Pichon, C.; Ayadi, M. A.; Abdelkafi, S. Optimized amylases extraction from oat seeds and its impact on bread properties. Int. J. Biol. 
Macromol. 72, 1213-1221(2015).

115) Uno-Okamura, K.; Soga, K.; Wakabayashi, K.; Kamisaka, S.; Hoson, T. Purification and properties of apoplastic amylase from oat (Avena sativa) seedlings. Physiologia Plantarum 121, 117-123(2004).

116) Sørensen, H. P.; Madsen, L. S.; Petersen, J.; Andersen, J. T.; Hansen, A. M.; Beck, H. C. Oat (Avena sati$v a)$ seed extract as an antifungal food preservative through the catalytic activity of a highly abundant class I chitinase. Appl. Biochem. Biotechnol. 160, 1573-1584(2010).

117) Ryan, L.; Thondre, P. S.; Henry, C. J. K. Oat-based breakfast cereals are a rich source of polyphenols and high in antioxidant potential. J. Food Compos. Anal. 24, 929-934(2011).

118) Viscidi, K. A.; Dougherty, M. P.; Briggs, J.; Camire, M. E. Complex phenolic compounds reduce lipid oxidation in extruded oat cereals. Lebensm.-Wiss u.Technol. 37, 789-796 (2004).

119) Cai, S.; Wang, O.; Wu, W.; Zhu, S.; Zhou, F.; Ji, B.; Gao, F.; Zhang, D.; Liu, J.; Cheng, Q. Comparative Study of the Effects of Solid-State Fermentation with Three Filamentous Fungi on the Total Phenolics Content (TPC), Flavonoids, and Antioxidant Activities of Subfractions from Oats (Avena sativa L.). J. Agric. Food Chem. 60, 507-513(2012).

120) Guo, W.; Wise, M. L.; Collins, F. W.; Meydani, M. Avenanthramides, polyphenols from oats, inhibit IL-1 $\beta$-induced NF-kB activation in endothelial cells. Free Radic. Biol. Med. 44, 415-429 (2008).

121) Peterson, D. M. Oat Antioxidants. J. Cereal Sci. 33, 115-129 (2001).

122) Peterson, D. M. Oat: A multifunctional grain. In: Proceedings of the $7^{\text {th }}$ International Oat Conference, Peltonen-Sainio, P.; Topi-Hulmi, M. (eds.), Jokioinen: MTT Agrifood Research Finland, Agrifood Research Reports 51, Helsinki, Finland, pp. 21-25(2004).

123) Suarna, C.; Hood, R. L.; Dean, R. T.; Stocker, R. Comparative antioxidant activity of tocotrienols and other natural lipid-soluble antioxidants in a homogeneous system, and in rat and human lipoproteins. Biochim. Biophys. Acta 1166, 163-170 (1993).

124) Serbinova, E.; Kagan, V.; Han, D.; Packer, L. Free radical recycling and intramembrane mobility in the antioxidant properties of alpha-tocopherol and alphatocotrienol. Free Rad. Biol. Med. 10, 263-275 (1991).

125) Peterson, D. M.; Jensen, C. M.; Hoffman, D. L.; Mannerstedt-Fogelforsl, B. Oat tocols: saponification vs. direct extraction and analysis in high-oil genotypes. Cereal Chem. 84, 56-60(2007).

126) Pihlava, J. M.; Eurola, M.; Hietaniemi, V.; Kontturi, M.; Vuorinen, M. Factors affecting the concentration of aventhramides in oats. In proceedings of the $7^{\text {th }}$ In- ternational Oat Conference, Helsinki, Finland, p. 119 (2004).

127) Kamal-Eldin, A.; Appelqvist, L. A. The chemistry and antioxidant properties of tocopherols and tocotrienols. Lipids 31, 671-701 (1996).

128) Peterson, D. M.; Qureshi, A. Genotype and environmental effects on tocols of barley and oats. Cereal Chem. 70, 157-162(1993).

129) Lasztity, R.; Berndorfer-Kraszner, E.; Huszar, M. On the presence and distribution of some bioactive agents in oat varieties. In 'Cereals for Food and Beverages. Recent Progress in Cereal Chemistry.' Inglett, G. E.; Munck L. (eds.), Academic Press, New York, pp. 429-445(1980).

130) Collins, F.W. Oat phenolics: avenanthramides, novel substituted N-cinnamoylanthranilate alkaloids from oat groats and hulls. J. Agric. Food Chem. 37, 60-66 (1989).

131) Collins, F. W. Oat phenolics: structure, occurrence, and function. In: Webster, F. H. editor. Oats: chemistry and technology. St. Paul, MN: American Association of Cereal Chemists, pp. 227-295(1986).

132) Ishihara, A.; Kojima, K.; Fujita, T.; Yamamoto, Y.; Nakajima, H. New series of avenanthramides in oat seed. Biosci. Biotechnol. Biochem. 13, 1-9(2014).

133) Liu, S.; Yang, N.; Hou, Z.; Yao, Y.; Lü, L.; Zhou, X.; Ren, G. Antioxidant Effects of Oats Avenanthramides on Human Serum. Agric. Sci. in China 10, 13011305 (2011).

134) Peterson, D. M.; Hahn, M. J.; Emmons, C. L. Oat avenanthramides exhibit antioxidant activities in vitro. Food Chem. 79, 473-478(2002).

135) Mayama, S.; Tani, T.; Matsuura, Y.; Ueno, T.; Fukami, $\mathrm{H}$. The production of phytoalexins by oat in response to crown rust, Puccinia coronata f. sp. Avenae. Physiol. Plant Pathol. 19, 217-226(1981).

136) Mayama, S.; Matsuura, Y.; Iida, H.; Tani, T. The role of avenalumin in the resistance of oat to crown rust, Puccinia coronata f. sp. avenae. Physiol. Plant Pathol. 20, 189-199 (1982).

137) Miyagawa, H.; Ishihara, A.; Nishimoto, T.; Ueno, T.; Mayama, S. Induction of avenanthramides in oat leaves inoculated with crown rust fungus, Puccinia coronata f. sp. Avenae. Biosci. Biotechnol. Biochem. 59, 2305-2306 (1995).

138) Bordin, A. P. A.; Mayama, S.; Tani, T. Potential elicitors for avenalumin accumulation in oat leaves. Ann. Phytopath. Soc. Jpn. 57, 688-695(1991).

139) Liu, L.; Zubik, L.; Collins, F. W.; Marko, M.; Meydani, M. The antiatherogenic potential of oat phenolic compounds. Atherosclerosis 175, 39-49 (2004).

140) Sur, R.; Nigam, A.; Grote, D.; Liebel, F.; Southall, M. D. Avenanthramides, polyphenols from oats, exhibit anti-inflammatory and anti-itch activity. Arch. Derma- 
tol. Res. 300, 569-574(2008).

141) Sosulski, F.; Krygier, K.; Hogge, L. Free, esterified, and insoluble-bound phenolic acids. 3. Composition of phenolic acids in cereal and potato flours. J. Agric. Food Chem. 30, 337-340(1982).

142) Xing, Y. M.; White, P. J. Identification and function of antioxidants from oat groats and hulls. J. Am. Oil Chem. Soc. 74, 303-307(1997).

143) Dimberg, L. H.; Molteberg, E. L.; Solheim, R.; Frølich, W. Variation in oat groats due to variety, storage and heat treatment. I: Phenolic compounds. J. Cereal Sci. 24, 262-272(1996).

144) Emmons, C. L.; Peterson, D. M. Antioxidant activity and phenolic contents of oat groats and hulls. Cereal Chem. 76, 902-906 (1999).

145) Graf, E.; Eaton, J. W. Antioxidant functions of phytic acid. Free Rad. Biol. Med. 8, 61-69 (1990).

146) Larsson, M.; Sandberg, A. S. Phytate reduction in oats during malting. J. Food Sci. 57, 994-997 (1992).

147) Saastamoinen, M.; Plaami, S.; Kumpulainen, J. $\beta$-Glucan and phytic acid content of oats cultivated in Finland. Acta Agric. Scandinavica Section B-Soil Plant Sci. 42, 6-11 (1992).

148) Miller, G. A.; Youngs, V. L.; Oplinger, E. S. Environmental and cultivar effects on oat phytic acid concentration. Cereal Chem. 57, 189-191 (1980).

149) Lolas, G. M.; Palamidis, N.; Markakis, P. The phytic acid-total phosphorus relationship in barley, oats, soybeans, and wheat. Cereal Chem. 53, 867-871 (1976).

150) Miller, G. A.; Youngs, V. L.; Oplinger, E. S. Effect of available soil phosphorus and environment on the phytic acid concentration in oats. Cereal Chem. 57, 192-194 (1980).

151) Knights, B. A. Identification of the sterols of oat seed. Phytochemistry 4, 857-862(1965).

152) Zhang, W. K.; Xu, J. K.; Zhang, L.; Du, G. H. Flavonoids from the bran of Avena sativa. Chin. J. Nat. Med. 10, 110-114(2012).

153) Tong, L. T.; Zhong, K.; Liu, L.; Guo, L.; Cao, L.; Zhou, S. Oat oil lowers the plasma and liver cholesterol concentrations by promoting the excretion of faecal lipids in hypercholesterolemic rats. Food Chem. 142, 129-134 (2014).

154) Chu, Y. F.; Wise, M. L.; Gulvady, A. A.; Chang, T.; Kendra, D. F.; Jan-Willem van Klinken, B.; Shi, Y.; O’Shea, M. In vitro antioxidant capacity and anti-inflammatory activity of seven common oats. Food Chem. 139, 426-431 (2013).

155) Wang, H. C.; Hung, C. H.; Hsu, J. D.; Yang, M. Y.; Wang, S. J.; Wang, C. J. Inhibitory effect of whole oat on aberrant crypt foci formation and colon tumor growth in ICR and BALB/c mice. J. Cereal Sci. 53, 73-77(2011).
156) Cai, S.; Huang, C.; Ji, B.; Zhou, F.; Wise, M. L.; Zhang, D.; Yang, P. In vitro antioxidant activity and inhibitory effect, on oleic acid-induced hepatic steatosis, of fractions and subfractions from oat (Avena sativa L.) ethanol extract. Food Chem. 124, 900-905(2011).

157) Thies, F.; Masson, L. F.; Boffetta, P.; Kris-Etherton, P. Oats and CVD risk markers: a systematic literature review. Br. J. Nutr. 112, S19-S30 (2014).

158) Thongoun, P.; Pavadhgul, P.; Bumrungpert, A.; Satitvipawee, P.; Harjani, Y.; Kurilich, A. Effect of oat consumption on lipid profiles in hypercholesterolemic adults. J. Med. Assoc. Thai. 96, S25-S32 (2013).

159) Rose, D. J. Impact of whole grains on the gut microbiota: the next frontier for oats? Br. J. Nutr. 112, S44-S49 (2014).

160) Thies, F.; Masson, L. F.; Boffetta, P.; Kris-Etherton, P. Oats and bowel disease: a systematic literature review. Br. J. Nutr. 112, S31-S43(2014).

161) Clemens, R.; van Klinken, B. J. The future of oats in the food and health continuum. Br. J. Nutr. 112, S75-S79 (2014).

162) Chang, H. C.; Huang, C. N.; Yeh, D. M.; Wang, S. J.; Peng, C. H.; Wang, C. J. Oat Prevents Obesity and Abdominal Fat Distribution, and Improves Liver Function in Humans. Plant Foods Hum. Nutr. 68, 18-23 (2013).

163) Al-Malki, A. L. Oat Attenuation of Hyperglycemia-Induced Retinal Oxidative Stress and NF-кB Activation in Streptozotocin-Induced Diabetic Rats. Evid. Based Complement Alternat. Med. 2013, 983923 (2013).

164) Peng, C. H.; Chang, H. C.; Yang, M. Y.; Huang, C. N.; Wang, S. J.; Wang, C. J. Oat attenuate non-alcoholic fatty liver and obesity via inhibiting lipogenesis in high fat-fed rat. J. Funct. Foods 5, 53-61 (2013).

165) Dong, J.; Cai, F.; Shen, R.; Liu, Y. Hypoglycaemic effects and inhibitory effect on intestinal disaccharidases of oat beta-glucan in streptozotocin-induced diabetic mice. Food Chem. 129, 1066-1071 (2011).

166) Boffetta, P.; Thies, F.; Kris-Etherton, P. Epidemiological studies of oats consumption and risk of cancer and overall mortality. Br. J. Nutr. 112, S14-S18 (2014).

167) Anonymous: BHP. British Herbal Pharmacopoeia. British Herbal Medicine Association, U.K, p. 37 (1983).

168) Huang, Y. F.; Poland, J. A.; Wight, C. P.; Jackson, E. W.; Tinker, N. A. Using Genotyping-By-Sequencing (GBS) for Genomic Discovery in Cultivated Oat. PLoS One 9, e102448(2014).

169) Oliver, R. E.; Lazo, G. R.; Lutz, J. D.; Rubenfield, M. J.; Tinker, N. A.; Anderson, J. M.; Wisniewski Morehead, N. H.; Adhikary, D.; Jellen, E. N.; Jeffrey Maughan, P.; Brown Guedira, G. L.; Chao, S.; Beattie, A. D.; Car- 
son, M. L.; Rines, H. W.; Obert, D. E.; Michael Bonman, J.; Jackson, E. W. Model SNP development for complex genomes based on hexaploid oat using highthroughput 454 sequencing technology. BMC Genomics 12, 77 (2011).
170) Bräutigam, M.; Lindlöf, A.; Zakhrabekova, S.; GhartiChhetri, G.; Olsson, B.; Olsson, O. Generation and analysis of 9792 EST sequences from cold acclimated oat, Avena sativa. BMC Plant Biol. 5, 18(2005). 